\title{
Oxidative Stress and Anti-oxidants in Pre and Post-operative Cases of Breast Carcinoma
}

\section{Operasyon Öncesi ve Sonrası Meme Kanseri Olgularında Oksidatif Stres ve Antioksidanlar}

\author{
(D) Sohail HUSSAIN ${ }^{1,2 *}$, (D) Mohammad ASHAFAQ ${ }^{2}$ \\ 'Aligarh Muslim University, J.N. Medical College, Department of Biochemistry, Uttar Pradesh, India \\ 2Jazan University, Faculty of Pharmacy, Department of Pharmacology and Toxicology, Jazan, Kingdom of Saudi Arabia
}

\begin{abstract}
Objectives: To investigate the existence of oxidative stress in the sera of patients with breast cancer and its effects on the consequent breast cancer.

Materials and Methods: This study included 50 control volunteers, 50 patients with breast cancer, and 50 patients with post-operative breast cancer. Patients with pre-operative cancer were clinically and histopathologically diagnosed for breast carcinoma with stage 0 , not having therapeutic history. The control 50 healthy female volunteers had the same socio-economic status, and no history of any cancer. After obtaining consent, venous blood was collected from the volunteers by vein puncture using a $10 \mathrm{~mL}$ sterile disposable syringe and needle. About $8 \mathrm{~mL}$ of blood was collected, $4 \mathrm{~mL}$ of which was poured into a heparinized bulb and $4 \mathrm{~mL}$ was allowed to clot. The levels of MDA, NO, GSH, and activities of RBC-SOD (in RBC lysate), NOS, copper and zinc GPx, and CAT, and vitamins A, C, and E metabolites were measured in the sera of each group.

Results: The activities of RBC-SOD and the levels of MDA, NO, as well as the NOS were significantly higher in the sera of all patients with breast cancer as compared with the controls. However, the levels of GSH and vitamins A, C, and E, as well as the activities of copper and zinc GPx and CAT were decreased in patients with breast cancer when compared with the controls.

Conclusion: The study provides further evidence for the presence of oxidative stress in the serum of patients with breast carcinoma. Patients with higher levels of MDA showed deficiencies of antioxidants and trace elements in the serum. A poor dietary antioxidant status and high oxidant levels are associated with the risk of breast cancer, thus suggesting that patients with breast cancer should take nutritive supplements to balance the antioxidant and oxidant levels for better outcomes.
\end{abstract}

Key words: Breast cancers, oxidants, antioxidants

öz

Amaç: Meme kanserli hastaların serumlarında oksidatif stresin varlığını ve meme kanserine etkilerini araştırmaktır.

Gereç ve Yöntemler: Bu çalışmaya 50 gönüllü kontrol, 50 meme kanseri hastası ve 50 ameliyat sonrası meme kanseri hastası dahil edildi. Bu hastalar, klinik ve histopatolojik olarak evre 0 meme kanseri teșhisi olan ve tedavi almamış hastalardır. Kontrol grubundaki 50 sağlıklı kadın gönüllü aynı sosyo-ekonomik statüye sahipti ve hiçbir kanser öyküsü yoktu. Onam alındıktan sonra, $10 \mathrm{~mL}$ 'lik steril tek kullanımlık bir şırınga ve iğne kullanılarak venöz ponksiyon ile gönüllülerden venöz kan alındı. Yaklaşık $8 \mathrm{~mL}$ kan toplandı, $4 \mathrm{~mL}$ 'si heparinize bir ampul içerisine alındı ve $4 \mathrm{~mL}$ 'si pıhtılașmaya bırakıldı. Her grubun serumunda MDA, NO, GSH ve RBC-SOD (RBC lizat), NOS, bakır ve çinko GPx ve CAT aktiviteleri, A, C ve E vitaminleri ölçüldü.

Bulgular: Meme kanseri olan tüm hastaların serumlarında RBC-SOD aktiviteleri, MDA, NO ve NOS düzeyleri, kontrollere göre anlamlı olarak daha yüksektir. Bununla birlikte, kontrol grubu ile karşılaştırıldığında meme kanseri olan hastalarda GSH, A, C ve E vitaminleri ile bakır ve çinko GPx ve CAT aktiviteleri azalmıştır.

Sonuç: Bu çalışma, meme kanseri hastalarının serumunda oksidatif stresin varlığına yönelik ileri kanıt sunmaktadır. Serumunda daha yüksek seviyelerde MDA bulunan hastaların antioksidan ve eser elementlerinin yetersiz olduğunu göstermiștir. Zayıf antioksidan diyet ve yüksek oksidan düzeyleri meme kanseri riski ile ilișkilidir, bu nedenle meme kanseri olan hastaların daha iyi sonuçlar için antioksidan ve oksidan seviyelerini dengeleyecek besleyici takviyeler almaları gerektiğini düșündürmektedir.

Anahtar kelimeler: Meme kanseri, oksidanlar, antioksidanlar

*Correspondence: E-mail: shussainamu@gmail.com, Phone: +90 557632511 ORCID-ID: orcid.org/0000-0001-6958-6191

Received: 09.02.2017, Accepted: 07.09.2017

๑Turk J Pharm Sci, Published by Galenos Publishing House. 


\section{INTRODUCTION}

Breast cancer is one of the most common malignant tumors in women with unknown etiology.' Reactive oxygen species (ROS) such as superoxide anion radical $\left(\downarrow \mathrm{O}_{2}\right)$, hydroxyl radicals $\left({ }^{\circ} \mathrm{OH}\right)$ and hydrogen peroxide $\left(\mathrm{H}_{2} \mathrm{O}_{2}\right)$ are produced during aerobic metabolism. ${ }^{2}$ Levels of free radicals are controlled by antioxidant enzymes [catalase (CAT), glutathione peroxidase (GPx), superoxide dismutase (SOD)] and anti-oxidants (vitamins E, C, glutathione, carotenoids and flavonoids). ${ }^{3}$ Under normal conditions, there is a balance between the activities of antioxidant enzymes and intracellular levels of these anti-oxidants. This balance is essential for the survival of organisms and their health. An imbalance between the production and detoxification of ROS results in oxidative stress. ROS has been implicated in the pathogenesis of certain diseases, including cancer. ${ }^{4.5}$ It reacts with polyunsaturated fatty acids to induce the release of toxic and reactive aldehyde metabolites such as malondialdehyde (MDA), one of the end products of lipid peroxidation (LPO). MDA may be involved in tumor promotion because it can interact with the functional groups of a variety of cellular compounds. ${ }^{6}$ To control the over production of ROS, cells protect themselves against oxidative damage by antioxidant detoxifying mechanisms, which helps to lower ROS concentrations in the body. SOD catalyzes the dismutation of $\mathrm{O}_{2} \downarrow$ into $\mathrm{H}_{2} \mathrm{O}_{2}$, and CAT is responsible for the detoxification of $\mathrm{H}_{2} \mathrm{O}_{2}$ to oxygen and water. ${ }^{7}$ Glutathione acts as a reducing agent that maintains enzymes in an active state as an antioxidant. ${ }^{8}$ The main protective roles of glutathione against oxidative stress are: (i) to act as a cofactor for several detoxifying enzymes such as glutathione reductase and GPx against oxidative stress; (ii) to participate in amino acid transport through the plasma membrane; (iii) to scavenge the $\left({ }^{\circ} \mathrm{OH}\right)$ and singlet oxygen, detoxifying the $\mathrm{H}_{2} \mathrm{O}_{2}$ and lipid peroxides by the catalytic action of $\mathrm{GPx}$, and (iv) to regenerate the most important antioxidants back to their active forms. ${ }^{89}$ Nitric oxide (NO) acts as an intracellular second messenger and provides an efficient system for cellular regulation, interaction, and defense. Its role strictly depends on the chemical reactivity with oxygen and metals. Recent studies revealed that the involvement of altered NO levels was associated in the pathogenesis of cervical cancer $(\mathrm{CaC} x) .^{10}$ Some findings have shown that concentration of NO higher or lower than the basal level caused a tumorigenic effect in CaCx." In addition to the body defense mechanism, there are vitamins that provide the body with much needed immunity and a mechanism of self-defense to fight against various pathogens. Studies indicate that the level of these antioxidants in the body decrease in carcinogenesis. The level of vitamin $E$ was found to vary in cervical carcinogenesis. ${ }^{12}$ Vitamin $C$ has free radical scavenging property, it directly reacts with hydroperoxides and plays an important role in sparing vitamin $\mathrm{E}$. Thus, the role of vitamin $C$ is very important in the treatment of cancer.12,13 Strong oxidizing agent such as NO, interacts with organic substances and with the support of transition metal like copper which creates more reactive species such as $\left({ }^{\circ} \mathrm{OH}\right) .^{14} \mathrm{Zinc}$ is an integral part of biomembranes, it may be involved in the control of membrane integrity, stability, and LPO -related injuries. Zinc plays an inhibitory role in RNA and DNA polymerase, phosphodiesterase, and an activating effect on the membranebound enzyme, adenylcyclase, and there is suggested role of zinc in carcinogenesis. ${ }^{15}$ The levels of LPO and antioxidant status in patients with breast cancer after surgery remain unknown. To address these issues, the levels of oxidants and antioxidants in the patients with breast cancer were examined during and after tumor removal.

\section{MATERIALS AND METHODS}

The present study was conducted in the Department of Biochemistry, Jawaharlal Nehru Medical College, Aligarh Muslim University, Aligarh, Uttar Pradesh, India. This study included 50 control volunteers, 50 patients with breast cancer, and 50 patients with post-operative breast cancer. Further, the women were within the age group of 35-65 years and were from the same demographic area. Patients with pre-operative cancer were clinically and histopathologically diagnosed for breast carcinoma with stage 0 , not having therapeutic history. The 50 healthy female control volunteers were from the same socio-economic status, had no history of smoking, alcoholism, and any cancer. Volunteers/patients with a history of smoking, alcoholism, and other diseases that induce oxidative stress such as diabetes mellitus, pulmonary diseases, and respiratory diseases were excluded from the study. The study was approved by the institutional ethics committee and written informed consent was received from the patients. After obtaining consent, venous blood was collected from the volunteers/patients under aseptic conditions by veinpuncture usinga $10 \mathrm{~mL}$ sterile disposable syringe and needle. About 8 $\mathrm{mL}$ of blood were collected, $4 \mathrm{~mL}$ of which was poured into a heparinized bulb and $4 \mathrm{~mL}$ was allowed to clot. Serum and plasma were separated by centrifugation at $3000 \mathrm{rpm}$ for 10 min at room temperature. The plasma pellets were taken as a source of red blood cells (RBCs). The samples were stored at $4^{\circ} \mathrm{C}$ before analysis and all the samples were analyzed on the day of collection.

\section{Assay of $L P O$}

Measurement of MDA in serum was estimated using the thiobarbituric acid (TBA) method. ${ }^{16,17}$ MDA, which is a stable end product of fatty acid peroxidation, reacts with TBA at acidic conditions to form a complex that has a maximum absorbance at $535 \mathrm{~nm}$. A $300 \mu \mathrm{L}$ sample was mixed with $1.5 \mathrm{~mL}$ of 0.05 $\mathrm{mol} / \mathrm{L} \mathrm{HCl}$ and $0.5 \mathrm{~mL}$ of $0.67 \%$ TBA and then mixed and boiled well in water at $\left(95^{\circ} \mathrm{C}\right)$ for $30 \mathrm{~min}$. After cooling, the products were extracted with $2 \mathrm{~mL}$ of $15 \%$ butanol and centrifuged at $2500 \mathrm{rpm}$ at $\left(4^{\circ} \mathrm{C}\right)$ for $30 \mathrm{~min}$. The rate of LPO was expressed as MDA formed per hour per milligram of protein using the molar extinction coefficient of $1.56 \times 10^{5} \mathrm{~mol} / \mathrm{L}^{-1} \mathrm{~cm}^{-1}$.

\section{Assay of SOD}

SOD activity was estimated using a commercial Ransod kit (Randox Laboratories, UK). This method is based on the generation of $\mathrm{O}_{2}$ produced by xanthine and xanthine oxidase, 
which react with phenyl tetrazolium chloride to form a red formazan dye. RBC-SOD activity was measured in RBC hemolysate through the degree of reaction inhibition. The results are expressed as $\mathrm{U} / \mathrm{mL}$. RBC-SOD was assessed using Winterbourn's method, which is based on the ability of SOD to inhibit the reduction of nitroblue tetrazolium by superoxide, which is generated by the reaction of photo-reduced riboflavin and oxygen. ${ }^{18}$

\section{Assay of CAT}

CAT activity was measured by monitoring the decrease in absorption of $\mathrm{H}_{2} \mathrm{O}_{2}$ at $240 \mathrm{~nm} .{ }^{19}$ One hundred microliters of serum was added to a $0.5 \mathrm{~mL}$ quartz cuvette containing 400 $\mu \mathrm{L}$ of $20 \mathrm{mM} \mathrm{H}_{2} \mathrm{O}_{2}$ in phosphate-buffered saline $\left(25^{\circ} \mathrm{C}\right.$ ) and mixed thoroughly by pipetting. The absorbance was monitored immediately at $240 \mathrm{~nm}$ for three minutes at one-minute intervals. CAT activity was measured for each sample and the rate in $\mathrm{mAU} / \mathrm{min} / \mathrm{mg}$ protein was averaged.

\section{Assay of GSH}

GSH status analyses were assayed from blood samples obtained through a venous arm puncture and the serum was separated by centrifugation. ${ }^{20}$ After the separation, the buffy coat was removed and the packed cells were washed 3 times with physiologic saline. One hundred-microliter aliquots of washed RBCs were added to $300 \mathrm{~mL}$ ice-cold $5 \%$ metaphosphoric acid. To completely precipitate proteins, the samples were vortexed and incubated on ice for $10 \mathrm{~min}$. After centrifugation at $4^{\circ} \mathrm{C}$ at $12000 \mathrm{rpm}$ for $10 \mathrm{~min}$, the supernatants were filtered through a $0.2 \mathrm{~mm}$ filter and diluted 5 times before being injected into the capillary electrophoresis system.

\section{GPx assay}

GPx activity was assayed according to the method of Haque et al. ${ }^{21}$ The assay mixture consisted of $0.1 \mathrm{M}$ phosphate buffer ( $\mathrm{pH}$ 7.4), $1 \mathrm{mM}$ EDTA, $1 \mathrm{mM}$ sodium azide, $1 \mathrm{mM}$ GSH, $0.2 \mathrm{mMNADPH}, 0.25 \mathrm{mM} \mathrm{H}_{2} \mathrm{O}_{2}$, and $0.1 \mathrm{~mL}$ sera. Oxidation of NADPH was recorded spectrophotometrically at $340 \mathrm{~nm}$. The enzyme activity was calculated as nanomoles of NADPH oxidized per minute per milligram of protein using a molar extinction coefficient of $6.22 \times 10^{3} \mathrm{M}^{-1} \mathrm{~cm}^{-1}$.

\section{NO assay}

Serum was deproteinized first to convert NO to nitrate, the stable product of NO. The nitrate present in the filtrate was then reduced to nitrite, which was measured by diazotization of sulphanilamide and coupled with naphthylethylene diamine, as in Najawa and Cortas's method. ${ }^{22}$

\section{Inducible NO (iNOS) assay}

iNOS synthase activity was measured in vitro in blood lymphocytes (suspended in MEM @ 1×106 viable cells $/ \mathrm{mL}$ ) using arginine and Greiss reagent with the method of Stuehr and Marletta. ${ }^{23}$ The optical density of the citrulline formed was determined spectrophotometerically with a ultraviolet-visible spectrophotometer (Shimazu) at $540 \mathrm{~nm}$ against a control.

\section{Assay of vitamins}

Serum vitamin $\mathrm{C}$ was estimated by the method of $\mathrm{Kyaw}^{24}$, where phosphotungstic acid was first deproteinized and then reacted with ascorbic acid to produce a blue color. Vitamins $A$ and $E$ were measured using high-performance liquid chromatography (HPLC) as per the modified method of Omu et al. ${ }^{25}$. In brief, $\alpha$-tocopherol acetate and retinol acetate were pipetted into an Eppendorf tube. Blood serum was added and vortexed; the hexane extract of vitamin $A$ and $E$ was taken out in a glass tube, dried under nitrogen stream, and dissolved into methanol. Finally, this preparation was injected into an HPLC fitted with reverse phase of column $\mathrm{C} 18$. The vitamins were eluted with methanol at a flow rate of $1.5 \mathrm{~mL} / \mathrm{min}$ for 15 minutes. The peak heights and curve areas of vitamin A, E, and acetates were measured to calculate the amount of these vitamins in the serum with an ultraviolet detector at $292 \mathrm{~nm}$.

\section{Assay of trace elements}

Copper and zinc in serum were estimated by using an atomic absorption spectrophotometer.

\section{Statistical analysis}

The experimental data are expressed as mean \pm standard deviation. In this study, $p$ values of $p<0.05$ were considered significant. Statistical analysis was performed using the STATGRAPHICS plus statistical package.

\section{RESULTS}

The results showed that the level of MDA was increased significantly in all groups of patients with breast cancer as compared with the controls ( $p<0.05)$. The MDA level was decreased $13.81 \%$ in post-operative patients as compared with pre-operative patients. On the other hand, the activity of RBC-SOD was significantly increased in pre-operative and post-operative patients $(p<0.05)$ as compared with controls, but its activity in post-operative patients was decreased $34.69 \%$ compared with pre-operative patients (Table 1). However, the activity of CAT was decreased significantly in all groups of patients with breast cancer compared with the controls ( $p<0.05$ ), but this activity in post-operative patients was increased $23.13 \%$ compared with pre-operative patients (Table 1).

The contents of GSH was increased $23.52 \%$ in the postoperative group compared with the preoperative group. The level of NO was decreased $24.32 \%$ in the post-operative group when compared with the pre-operative group, and iNOS activity was also decreased $38.01 \%$ in the post-operative group as compared with the pre-operative group (Table 1). Significantly decreased RBC-SOD activity $(p<0.05)$ and plasma levels of vitamins $C$, $A$, and $E(p<0.05)$ were observed in all patients with cancer when compared with the healthy controls. It was observed that the concomitant decline in the activity of RBC-SOD and levels of vitamins were associated with the progression of cancer, but the levels of all vitamins were not significant in postoperative patients (Table 2). The $\mathrm{Cu} / \mathrm{Zn}$ ratio was also found to be significantly $(p<0.05)$ lower in post-operative patients when compared with the pre-operative. 
Table 1. Serum levels of oxidants and antioxidative enzymes in control and in patients with breast cancer before and after surgery

\begin{tabular}{lllll} 
Parameters & Control & Pre-operative & Post-operative & $\begin{array}{l}\text { Percentage change in post-operative } \\
\text { group }\end{array}$ \\
\hline NO $(\mu \mathrm{M} / \mathrm{L})$ & $36.56 \pm 6.13$ & $78.34 \pm 12.79^{*}(114.44 \%)$ & $59.28 \pm 11.61^{\#}(-24.33 \%)$ & $\downarrow 24.33^{*}$ \\
\hline iNOS (nmoles $/ \mathrm{mL} / \mathrm{min})$ & $1.19 \pm 0.53$ & $3.92 \pm 0.77^{*}(229.41 \%)$ & $2.43 \pm 0.51^{\#}(-38.01 \%)$ & $\downarrow 38.01^{*}$ \\
\hline MDA $(\mu \mathrm{M} / \mathrm{L})$ & $2.13 \pm 0.69$ & $3.098 \pm 1.02^{*}(45.07)$ & $2.67 \pm 0.94^{\#}(13.81)$ & $\downarrow 13.81$ \\
\hline SOD $(\mathrm{U} / \mathrm{mL})$ & $390.99 \pm 58.76$ & $712.43 \pm 154.87^{*}(82.21)$ & $465.88 \pm 113.57^{\#}(34.69)$ & $\downarrow 34.69^{*}$ \\
\hline RBC-SOD (units/mg) & $362513 \pm 217.9$ & $2387.34 \pm 398.97^{*}(99.24)$ & $2669.48 \pm 276.9^{\#}(10.56)$ & $\uparrow 10.56$ \\
\hline GSH (mM/L) & $0.64 \pm 0.1017$ & $0.39 \pm 0.1943^{*}(-39.06 \%)$ & $0.51 \pm 0.3109^{\#}(30.77)$ & $\uparrow 30.77 \%$ \\
\hline GPx $(\mathrm{U} / \mathrm{L})$ & $26673.37 \pm 3994.56$ & $8304.40 \pm 1856^{*}(-68.86)$ & $10234.43 \pm 2743^{\#}(18.85)$ & $\uparrow 18.85$ \\
\hline CAT $(\mathrm{U} / \mathrm{mL})$ & $78.68 \pm 8.51$ & $44.98 \pm 16.78^{*}(-42.83)$ & $58.52 \pm 21.79^{\#}(23.13)$ & $\uparrow 23.13^{*}$ \\
\hline
\end{tabular}

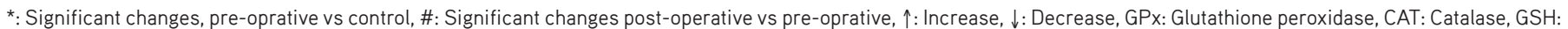
Glutathione, RBC-SOD: Red blood cell-superoxide dismutase, MDA: Malondialdehyde, NO: Nitric oxide, iNOS: Inducible nitric oxide

Table 2. Serum levels of vitamins and trace elements incontrols and in patients with breast cancer before and after surgery

$\begin{array}{lllll} & \text { Control } & \text { Pre-operative } & \text { Post-operative } & \text { Percentage change in post-operative } \\ \text { group }\end{array}$

": Significant changes, $\uparrow:$ Increase, $\downarrow$ : Decrease

\section{DISCUSSION}

Increased oxidative stress and LPO are implicated in carcinogenic processes. The magnitude of this damage depends on ROS levels and on the body defense mechanisms against them, which are mediated by various cellular antioxidants.,26 MDA is produced by the oxidation of polyunsaturated fatty acids in membranes induced by free radicals, and is an indicator of oxidative damage. Many studies have examined the possibility of a connection between LPO and cancer. ${ }^{6,27}$ Higher plasma MDA levels have been reported in patients with cancer than in controls. ${ }^{27}$ However, lower LPO measured in plasma using TBA-reactive substances has also been reported in breast cancer groups compared with controls. ${ }^{28}$ Our findings are in agreement with most earlier studies that suggested that there might be some accumulation of ROS, which causes significantly higher LPO at cellular and molecular levels. ROS derived from $\mathrm{NO}^{\bullet}$ and released from inflammatory cells. Radical can act on neighboring dividing epithelial cells, leading to somatic mutations in crucial cancer-causing genes. ${ }^{29} \mathrm{NO} \cdot$ produced in solid tumors has been implicated in enhanced vascular permeability, and increased tumor blood flow, and hence sustained tumor growth. ${ }^{30} \mathrm{GSH}$, as a reductant, is very important in maintaining the stability of erythrocyte membranes. It is implicated in the cellular defense against xenobiotics and deleterious compounds such as free radicals and hydroperoxides. ${ }^{31} \mathrm{GSH}$ in the nucleus also maintains the redox state of critical protein sulphydryls that are necessary for DNA repair and expression. ${ }^{8}$ A decrease in blood GSH in circulation has been reported in several diseases including malignancies. ${ }^{32}$ The lower GSH levels in patients with breast cancer supports the hypothesis that glutathione status is inversely related in malignant transformation. ${ }^{33}$ Several studies have reported decreased levels of GSH in the blood of patients with breast cancer compared with control subjects.34,35 Our results showed that there were significant decreases in blood GSH levels in patients with breast cancer compared with the control subjects. The decrease in GSH concentration can be explained by decreased GSH synthesis and/or increased GSH consumption in the removal of peroxides and xenobiotics. Cells have strong endogenous antioxidant defenses against increased LPO, ROS, and NO. SOD and CAT are the first line of defense against superoxide and $\mathrm{H}_{2} \mathrm{O}_{2}{ }^{36,37}$ The significant increase in SOD activities indicates the formation of more superoxide radicals and their removal because SOD metabolizes superoxide radicals. ${ }^{38}$ Furthermore, the decrease in activity of SOD might be due to an association with free radical generation, which causes damage to enzymes by cross linking or damaging the nuclear DNA, leading to mutations. It may also be due to a scarcity of trace elements such as zinc and manganese, which act as cofactors for this enzyme. ${ }^{39}$ However, the significant decrease in CAT activity indicates the toxicity produced by $\mathrm{H}_{2} \mathrm{O}_{2}{ }^{27}$ Studies have shown that oxidants may activate gene expression through antioxidant responsive elements, ${ }^{40}$ which explains the enhanced enzyme activities. Our data showed a significant increase in SOD and a decrease in 
CAT activities in patients with breast cancer compared with the controls. A substantial increase in GSH level and increase CAT activity were found in the postoperative patients, which might be due to the free radical scavenging property. The decreased levels of vitamin $C$ may be associated with its action as an antioxidant where it gets used. Its synergism with vitamin $\mathrm{E}$ and A helps in sparing vitamin E, and during this process, vitamin $C$ gets used, 12,13 which is seen through the significant decline in plasma ascorbic acid. A negative correlation between vitamin $C$ and MDA was noted, thereby leading to the conclusion that free radicals are scavenged by ascorbic acid and thus get utilized. Copper can interact directly with the bases of DNA at G-C sites. ${ }^{41}$ The addition of copper to DNA in vitro mediates more extensive DNA base damage, inducing more mutations. ${ }^{42}$ Copper may also elaborate other free radical species such as ${ }^{\circ} \mathrm{OH}$; therefore, the inactivation/loss of certain tumor suppressor genes can lead to the initiation and/or progression of carcinogenesis. The elevation in copper levels may be due to mobilization of copper from tissue to serum. ${ }^{42}$

Zinc is used for cell growth and maintains the integrity of the membrane. However, cancerous cells may consume the zinc present in the circulation for tumor growth and maintain membrane integrity. ${ }^{43}$ This might be a possible reason for the depletion of zinc in breast cancer. The increased ratio of $\mathrm{Cu} /$ $\mathrm{Zn}$ is due to the significant decrease in $\mathrm{Zn}$ and concomitant increase in copper. Therefore, in the pre-operative group, the ratio of $\mathrm{Cu} / \mathrm{Zn}$ was increased as compared with the controls. As this ratio is altered, this could be considered as a risk factor for tumor growth or carcinogenesis.

\section{CONCLUSIONS}

In conclusion, breast cancer is related to an increase of oxidants in serum with concomitant decrease of antioxidant defense capacity. Overall, our data support the importance of endogenous antioxidant in the etiology of breast cancer across all levels of predicted risk. There are some significant differences in the oxidant and antioxidant status in the blood of patients with breast cancer before and after surgery. Prospective studies in a larger population should be conducted to confirm our present findings.

\section{ACKNOWLEDGEMENTS}

The author thanks to Aligarh Muslim University, Aligarh, Uttar Pradesh, India, for financial assistance.

Conflict of Interest: No conflict of interest was declared by the authors.

\section{REFERENCES}

1. Jemal A, Tiwari RC, Murray T, Ghafoor A, Samuels A, Ward E, Feuer EJ, Thun MJ; American Cancer Society. Cancer statistics, 2004. CA Cancer J Clin. 2004;54:8-29.

2. Rajneesh CP, Manimaran A, Sasikala KR, Adaikappan P. Lipid peroxidation and antioxidant status in patients with breast cancer. Singapore Med J. 2008;49:640-643.
3. Hou MF, Lin SB, Yuan SS, Tsai SM, Wu SH, Ou-Yang F, Hsieh JS, Tsai KB, Huang TJ, Tsai LY. The clinical significance between activation of nuclear factor kappa B transcription factor and overexpression of HER2/neu oncoprotein in Taiwanese patients with breast cancer. Clin Chim Acta. 2003;334:137-144.

4. Tsai LY, Lee KT, Liu TZ. Evidence for accelerated generation of hydroxyl radicals in experimental obstructive jaundice of rats. Free Radic Bio Med. 1998;24:732-737.

5. Polat MF, Taysi S, Gul M, Cikman O, Yilmaz I, Bakan E, Erdogan F. Oxidant/ antioxidant status in blood of patients with malignant breast tumor and benign breast disease. Cell Biochem Funct. 2002;20:327-331.

6. Vaca CE, Wilhelm J, Harms-Ringdahl M. Interaction of lipid peroxidation products with DNA. A review. Mutat Res. 1988;195:137-149.

7. Gönenç A, Erten D, Aslan S, Akinci M, Simşek B, Torun M. Lipid peroxidation and antioxidant status in blood and tissue of malignant breast tumor and benign breast disease. Cell Biol Int. 2006;30:376-380.

8. Estrela JM, Ortega A, Obrador E. Glutathione in cancer biology and therapy. Crit Rev Clin Lab Sci. 2006;43:143-181.

9. Bakan N, Taysi S, Yilmaz O, Bakan E, Kuşkay S, Uzun N, Gündoğdu M. Glutathione peroxidase, glutathione reductase, $\mathrm{Cu}-\mathrm{Zn}$ superoxide dismutase activities, glutathione, nitric oxide and malondialdehyde concentrations in serum of patients with chronic lymphocytic leukemia. Clin Chim Acta. 2003;338:143-149.

10. Beevi SS, Rasheed MH, Geetha A. Evidence of oxidative and Nitrosative stress in patients with Cervical squamous cell carcinoma. Clin Chim Acta. 2007;375:119-123.

11. Ioannidis I, Batz M, Paul T, Korth HG, Sustmann R, Groot HD. Enhanced release of nitric oxide causes increased cytotoxicity of s-nitro-N-acetylDL-penicillamine and sodium nitroprusside under hypoxic condition. Biochem J. 1998;318:789-795.

12. Niki E. Action of ascorbic acid as a scavenger of active stable oxygen radicals. Am J Clin Nutr. 1991;54:195-145.

13. Head KA. Ascorbic acid in the prevention and treatment of cancer. Altern Med Rev. 1998;3:174-186.

14. Gorodetsky R, Fuks Z, Sulkes A, Ginsburg H, Weshler Z. Correlation of erythrocyte and plasma levels of zinc, copper and iron with evidence of metastatic spread in cancer patients. Cancer. 1985;55:779-787.

15. Morton KS. Role of trace elements in cancer. Cancer Research. 1975;35:3481-3487.

16. Tsai LY, Lee KT, Tsai SM, Lee SC, Yu HS. Changes of lipid peroxide levels in blood and liver tissue of patients with obstructive jaundice. Clin Chim Acta. 1993;215:41-50.

17. Buege JA, Aust SD. Microsomal lipid peroxidation. Methods Enzymol. 1978;52:302-310.

18. Winterbourn CC, Hawkins RE, Brian M, Carrell RW. The estimation of red cell superoxide dismutase activity. J Lab Clin Med. 1975;85:337-341.

19. Aebi H. Catalase in vitro. Methods Enzymol. 1984;105:121-126.

20. Carru C, Zinellu A, Pes GM, Marongiu G, Tadolini B, Deiana L. Ultrarapid capillary elec-trophoresis method for the determination of reduced and oxidized glutathione in red blood cells. Electrophoresis. 2002;23:17161721.

21. Haque R, Bin-Hafeez B, Parvez S, Pandey S, Sayeed I, Ali M, Raisuddin $\mathrm{S}$. Aqueous extract of walnut (Juglans regia L.) protects mice against cyclophosphamide induced biochemical toxicity. Hum Exp Toxicol. 2003;22:473-480. 
22. Cortas NK, Wakid NW. Determination of inorganic nitrate in serum and urine by kinetic cadmium reduction method. Clin Chem. 1990;36:14401443.

23. Stuehr DJ, Marletta MA. Synthesis of nitrite and nitrate in murine macrophage cell lines. Cancer Res. 1987;47:5590-5594.

24. Kyaw A. A simple colorimetric method for ascorbic acid determination in blood plasma. Clin Chim Acta. 1978;86:153-157.

25. Omu AE, Fatinikun T, Mannazhath N, Abraham S. Significance of Simultaneous Determination of serum and seminal plasma a tocopherol and retinol I in infertile men by high- performance liquid chromatography. Andrologia. 1999;31:347-354.

26. Z Zengin E, Atukeren P, Kokoglu E, Gumustas MK, Zengin U. Alterations in lipid peroxidation and antioxidant status in different types of intracranial tumors within their relative peritumoral tissues. Clin Neurol Neurosurg. 2009;111:345-351.

27. Gönenç A, Erten D, Aslan S, Akinci M, Simşek B, Torun M. Lipid peroxidation and antioxidant status in blood and tissue of malignant breast tumor and benign breast disease. Cell Biol Int. 2006;30:376-380.

28. Kumaraguruparan R, Subapriya R, Viswanathan P, Nagini S. Tissue lipid peroxidation and antioxidant status in patients with adenocarcinoma of the breast. Clin Chim Acta. 2002;325:165-170.

29. Hussain SP, Hofseth LJ, Harris CC. Radicals causes of cancer. Nat Rev Cancer. 2003;3:276-285.

30. Tamir S, Burney S, Tannenbaum SR. DNA damage by nitric oxide. Chem Res Toxicol. 1996;9:821-827.

31. Pastore A, Federici G, Bertini E, Piemonte F. Analysis of glutathione: Implication in redox and detoxification. Clin Chim Acta. 2003;333:19-39.

32. Yeh CC, Hou MF, Tsai SM, Lin SK, Hsiao JK, Huang JC, Wang LH, Wu $\mathrm{SH}$, Hou LA, Ma H, Tsai LY. Superoxide anion radical, lipid peroxides and antioxidant status in the blood of patients with breast cancer. Clin Chim Acta. 2005;361:104-111.
33. Kumaraguruparan R, Subapriya R, Kabalimoorthy J, Nagini S. Antioxidant profile in the circulation of patients with fibroadenoma and adenocarcinoma of the breast. Clin Biochem. 2002;35:275-279.

34. Lamari F, La Schiazza R, Guillevin R, Hainque B, Foglietti MJ, Beaudeux $\mathrm{JL}$, Bernard M. Biochemical exploration of energetic metabolism and oxidative stress in low grade gliomas: Central and peripheral tumor tissue analysis. Ann Biol Clin (Paris). 2008;66:143-150.

35. M. Gago-Dominguez X, Jiang X, Esteban Castelao J. Lipid peroxidation and the protective effect of physical exercise on breast cancer. Med Hypotheses. 2007;68:1138-1143.

36. Nair $U$, Bartsch $H$, Nair J. Lipid peroxidation induced DNA damage in cancer prone inflammatory diseases: A review of published adduct types and levels in humans. Free Radic Biol Med. 2007;43:1109-1120.

37. Khanzode SS, Muddeshwar MG, Khanzode SD, Dakhale GN. Antioxidant enzymes and lipid peroxidation in different stages of breast cancer. Free Radic Res. 2004;8:81-85.

38. Aggarwal S, Subberwal M, Kumar S, Sharma M. Brain tumor and role of betacarotene, a-tocopherol, superoxide dismutase and glutathione peroxidase. J Cancer Res Ther. 2006;2:24-27.

39. Manoharan S, Kolanjiappan K, Kayalvizhi M. Enhanced Lipid peroxidation and impaired enzymatic antioxidant activities in the erythrocytes of the patients with cervical carcinoma. Cell Mol Bio Lett. 2004;9:699-707.

40. Gago-Dominguez M, Castelao JE, Pike MC, Sevanian A, Haile RW. Role of lipid peroxidation in the epidemiology and prevention of breast cancer. Cancer Epidemiol Biomarkers Prev. 2005;14:2829-2839.

41. Chen CA, Hwang JL, Kuo TL, Hsieh CY, Huang SC. Serum copper and zinc levels in patients with cervical cancer. J Formos Med Assoc. 1990;89:677-682.

42. Singh M, Dwivedi S, Singh G, Bajpai M. Serum copper levels in different stages of carcinoma. Ind J Matern Child Health. 1990;1:12-14.

43. Beerheide W, Bernard HU, Tan YJ, Ganesan A, Rice WG, Ting AE. Potential drugs against cervical cancer. Zinc-ejecting inhibitors of the human papillomavirus Type 16 E6 oncoprotein. J Natl Cancer Inst. 1999;91:1211-1220. 